\title{
A rare case of ruptured ovarian ectopic pregnancy
}

\author{
Usha Kumari Chaudhary ${ }^{1}$, Reena Sharma ${ }^{2} *$, Arvind Kumar ${ }^{3}$, \\ Ajay Sharma ${ }^{4}$, Kewal Arun Mistry ${ }^{5}$
}

\author{
${ }^{1}$ Department of Dr. Rajendra Prasad Govt. Medical College, Tanda, Kangra, H.P., India \\ ${ }^{2}$ Department of Obstetrics \& Gynaecology, Dr. Rajendra Prasad Govt. Medical College, Tanda, Kangra, H.P., India \\ ${ }^{3}$ Department of Pharmacology, Dr. Rajendra Prasad Govt. Medical College, Tanda, Kangra, H.P., India \\ ${ }^{4}$ Department of Cardiology, Dr. Rajendra Prasad Govt. Medical College, Tanda, Kangra, H.P., India \\ ${ }^{5}$ Department of Radiology, Dr. Rajendra Prasad Govt. Medical College, Tanda, Kangra, H.P., India
}

Received: 07 July 2015

Revised: 08 July 2015

Accepted: 13 August 2015

\section{*Correspondence: \\ Dr. Reena Sharma, \\ E-mail: dreenajay@gmail.com}

Copyright: () the author(s), publisher and licensee Medip Academy. This is an open-access article distributed under the terms of the Creative Commons Attribution Non-Commercial License, which permits unrestricted non-commercial use, distribution, and reproduction in any medium, provided the original work is properly cited.

\section{ABSTRACT}

An ovarian ectopic pregnancy is a rare presentation. A 31 years old female presented with acute abdomen at period of gestation 8 weeks. Ultrasonography showed complex mass in Rt. adnexa of size of $6.32 \times 3.80 \mathrm{~cm}$. Emergency laparotomy was done under general anaesthesia and ruptured right ovary found. Right salpingo-oophrectomy and left tubectomy was done. The histopathological examination confirmed the ovarian ectopic pregnancy.

Keywords: Ectopic pregnancy, Laparotomy, Ovarian ectopic pregnancy

\section{INTRODUCTION}

Ovarian ectopic pregnancy is a rare presentation and constitutes only 0.15 to $3 \%$ of all ectopic pregnancies. ${ }^{1}$ We are presenting a case of ruptured ovarian ectopic pregnancy which presented for the emergency exploratory laparotomy.

\section{CASE REPORT}

It is a case of a 31 years, married, G3P2002, female presented to emergency department with history of amennorrhoea of 56 days with pain abdomen for 2 days. Patient had pain abdomen for 2 days which was acute in onset and progressive in nature. Patient had menarche at 14 years and had regular 30 days cycle. Her POG 8 weeks according to her last menstrual period. Patient is G3P2002. Patient had two live births, 10 years son and 5 years daughter, both delivered vaginally. No h/o taking treatment for infertility, PID. Her urine pregnancy test was positive but it was not confirmed by USG. Patient presented with pain abdomen acute in onset, severe in intensity, and progressive in nature. On examination patient was pale, heart rate was 110 beats per minute, NIBP 90/60 mmHg. There was no history of fever or vomiting. The respiratory and cardiovascular system appeared normal.

On per abdomen examination, guarding and rigidity present. Bowel sounds were present. On per speculum examination cervix and vagina were healthy and on per vaginum examination, cervix soft. Uterus bulky with right adnexal mass of approximately $7 \times 4 \mathrm{~cm}$ with right fornix tender. Emergency ultrasound was done to confirm the diagnosis and showed no intrauterine pregnancy with complex mass in right adnexa of size of $6.32 \times 3.80 \mathrm{~cm}$. with moderate free fluid in abdomen cavity (Figure 1). 
Haemoglobin was $7.5 \mathrm{gm} \%$ and blood group was B and $\mathrm{Rh}$ factor positive. Her viral markers were negative for HIV, HBsAg and HCV. After preoperative check-up patient was taken for exploratory laparotomy under general anaesthesia. About $300 \mathrm{ml}$ of haemoperitoneum and $200 \mathrm{ml}$ of old clots were removed from peritoneal cavity. Uterus was normal in size. Right tube was apparently normal looking. Rt. ovary had ruptured on its posterior surface about $2 \times 2 \mathrm{~cm}$ which was bleeding actively (Figure 2). Lt. ovary and tube were normal looking. Right sided salpingo-oopherectomy along with left tubectomy was done. Peritoneal toileting done. Abdomen closed and drain kept. One unit of blood transfusion given. The histopathological examination was done by pathologist and was suggestive of ovarian pregnancy.

Post-operative period was uneventful. Patient was discharged after 7 days.

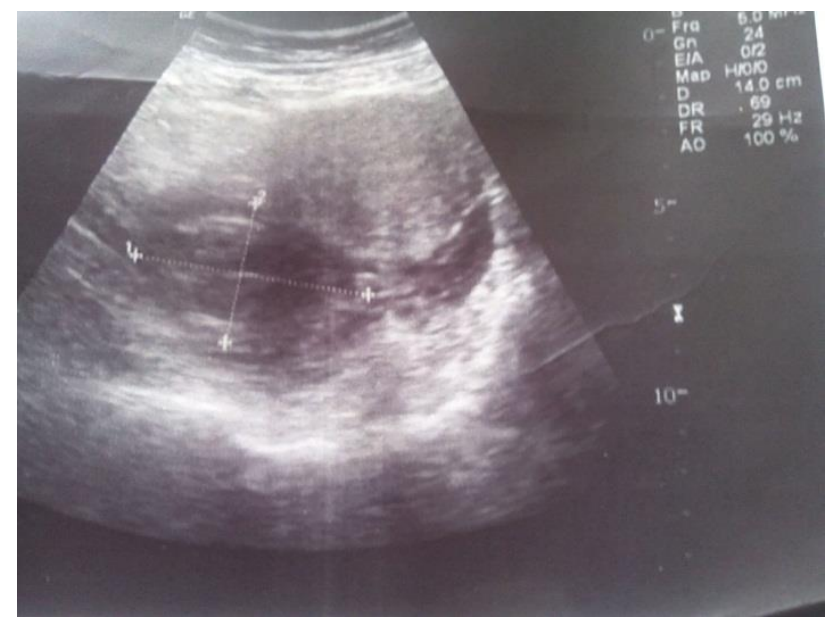

Figure 1: Shows the ultrasonography of the patient showing the right adnexal mass of size $6.32 \times 3.80 \mathrm{~cm}$.

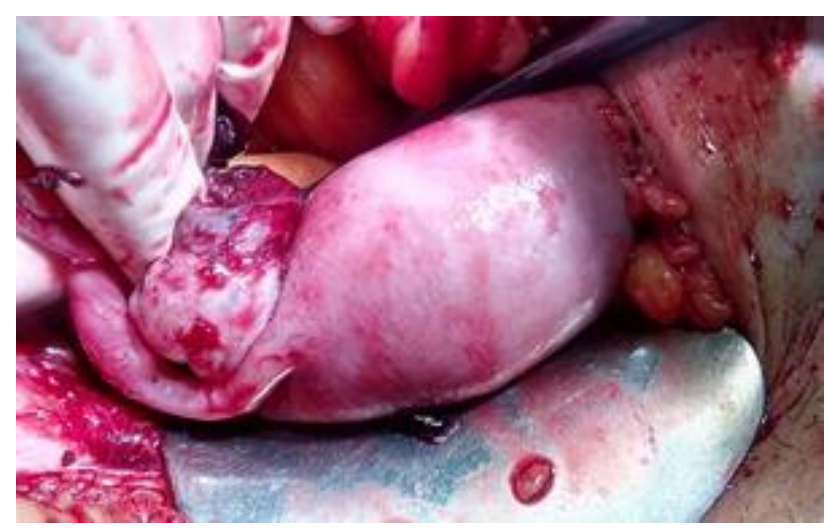

Figure 2: Ruptured right ovary on the posterior surface with the intact right fallopian tube.

\section{DISCUSSION}

Ectopic pregnancy is responsible for $10 \%$ of maternal mortality. ${ }^{1}$ Primary ovarian pregnancy is very uncommon among all types of extrauterine pregnancies, incidence of which is $0.15 \%-3 \%{ }^{1}$

Spiegelberg suggested four criteria to distinguish a primary ovarian pregnancy from a distal tubal pregnancy which secondarily involved the ovary. They are: 1) the fallopian tube with its fimbriae should be intact and separate from the ovary 2) the gestational sac should occupy the normal position of the ovary 3 ) the gestational sac should be connected to the uterus by the ovarian ligament 4) a histologically proven ovarian tissue should be located in the sac wall. ${ }^{2}$

Mean age of the patient reported with primary ovarian pregnancy is 29 years (Phillipe) whereas our patient was 31 years old. Patient was having regular menstrual cycle of 3-4 days every 28 days, There was no h/o infertility, PID, IUCD insertion and OCP's intake. Ovarian pregnancy occurs in fertile patients in contrary to tubal ectopic pregnancy which is commonly seen in patients with h/o infertility. ${ }^{3}$ Mean gestation age in literature is 45days whereas our patients had amenorrhoea of 56 days. Patient usually presents with pain abdomen (100\%), vaginal bleeding $(33 \%)$ and hypovolumic shock $(8 \%){ }^{2}$ Our patient presented with history of abdominal pain and was in hypovolemic shock.

Causes of ovarian pregnancy remain obscure. Some hypothesis are like fertilization of ovum inside the ovary or implantation of fertilized ovum in ovary, PID, reverse migration of embryo, tubal diseases and malfunction thickened tunica albuginea, ${ }^{1,2}$ interference with release of ovum from ruptured follicles. ${ }^{4,5}$ It is also reported with IVF and IUCD's. ${ }^{2}$ However no such association was seen in our case.

Serum beta HCG may also be used for diagnosis but TVS is the useful diagnostic tool. ${ }^{6}$ However abdominopelvic USG cannot always differentiate it from other types of ectopic pregnancies. ${ }^{7}$ Experienced sonologist can demonstrate hypoechoic adnexal mass as our sonologist diagnosed it as a right adnexal mass with moderate amount of free fluid in peritoneal cavity. Laparoscopy is very important tool for diagnosis as well treatment. ${ }^{2}$ Ovarian pregnancy usually rupture in $91 \%$ of cases in first trimester. ${ }^{2}$ Our patient had POG of 8 weeks. Laparoscopy is considered as gold standard of modern management of ovarian pregnancy. This technique is not available in resource poor settings as in our case so emergency laparotomy was done and right salphingooophrectoy done along with left tubal ligation as patient was having two children and had consented for permanent sterilization also.

\section{CONCLUSION}

Ruptured ovarian ectopic pregnancy is rare presentation. The presence of adnexal mass on ultrasonography along with clinical suspicion can lead to an early diagnosis and management of patient. 
Funding: No funding sources

Conflict of interest: None declared

Ethical approval: Not required

\section{REFERENCES}

1. Philippe E, Renaud R, Dellenbach P, Dreyfus J, Ritter J, Muhlstein C. Ovarian pregnancy. Apropos of 32 cases. J Gynecol Obstet Biol Reprod. 1987;16(7):901-8.

2. Raziel A, Schachter M, Mordechai E, Friedler S, Panski M, Ron-El R. Ovarian pregnancy - a 12-year experience of 19 cases in one institution. Eur J Obstet Gynecol Reprod Biol. 2004;114(1):92-6.

3. Seinera P, Gregorio A, Arisio R, Decko A, Crana F. Ovarian pregnancy and operative laparoscopy: Report of eight cases. Hum Reprod. 1998;12(3):60810 .
4. Scutiero G, Digioria P, Spada A, Greco P. Primary ovarian pregnancy and its management. JSLS. 2012;16:492-4.

5. Ramachandran T, Sharma S, Pratap K, Rajesh B, Akhila V, Ramayapally T, et al. Ovarian pregnancy following intracytoplasmic sperm injection and embryo transfer: a case report. Case Rep Obstet Gynecol. 2012;2012:38910.

6. Royal College of Obstetricians and Gynaecologists. Management of tubal pregnancy. Green Top Guidelines. London: RCOG; Guideline No. 21; May 2004.

7. Sergent F, Mauger-Tinlot F, Gravier A, Verspyck E, Marpeau L. Ovarian pregnancy: reappraisal of diagnostic criteria. J Gynecol Obstet Biol Reprod. 2002;31:741-6.

Cite this article as: Chaudhary UK, Sharma R, Kumar A, Sharma A, Mistry KA. A rare case of ruptured ovarian ectopic pregnancy. Int J Reprod Contracept Obstet Gynecol 2015;4:1568-70. 